\title{
Effect of probiotics as a complement to non-surgical periodontal therapy in chronic periodontitis: a systematic review
}

\author{
Anna Vives-Soler, Eduardo Chimenos-Küstner
}

Unity of Oral Medicine, Department of Odontostomatology, University of Barcelona

Correspondence:

C/Sabino Arana, 6, 10th floor 1st door

08028, Barcelona, Spain

avivessoler@gmail.com

Received: 08/04/2019

Accepted: $23 / 12 / 2019$

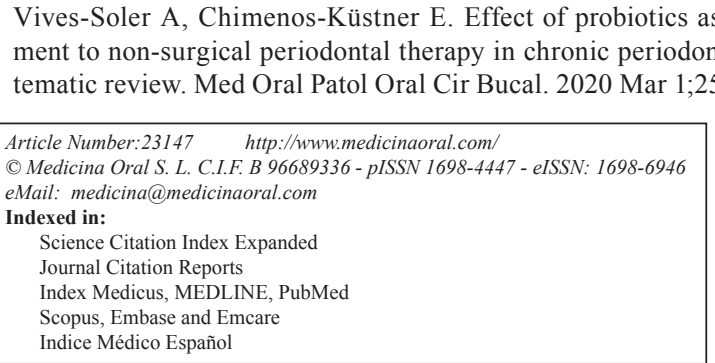

\begin{abstract}
Background: To improve the results of the classic periodontal treatment, probiotics have been suggested recently to decrease the number of bacteria and the expression of mediators of inflammation. This systematic review aimed to assess the literature for the effectiveness of different probiotic strains as adjuvants to non-surgical periodontal therapy. Material and Methods: The electronic database of MEDLINE (via Pubmed) was searched up to December 2017 for randomised clinical trials in English comparing non-surgical periodontal treatment and probiotics versus periodontal treatment and placebo. The primary outcome investigated was reduction in pocket probing depth. Secondary outcomes were bleeding on probing, plaque index reduction and bacteria counts.

Results: Nine trials were included. A narrative data synthesis did not result in any major improvement of overall pocket probing depth but moderate pockets from 4 to $6 \mathrm{~mm}$ showed larger reductions in study groups, which could decrease the need for surgery. Sites with bleeding on probing and presence of plaque decreased after treatment. For periimplant mucositis, there was a small tendency to better results in the study group.

Conclusions: With the available data, it is concluded that probiotics may provide an additional benefit to manual debridement in chronic periodontitis. More studies are required on dose, route of administration and strains of probiotics used.
\end{abstract}

Key words: Periodontics, chronic periodontitis, probiotics, periodontal treatment, lactobacillus, streptococcus.

\section{Introduction}

Periodontal disease is defined as an inflammation of the supporting tissues of the teeth, leading to loss of bone and periodontal ligament. Some oral bacteria species, organised in biofilms, are considered one of the main etiologic factors, triggering a local destructive inflam- matory reaction that creates periodontal pockets. Conventional periodontal treatment is mainly comprised of mechanical debridement, since both the disruption of the biofilm and the restoration of a biologically acceptable root surface are important in periodontitis progression (1). Thus, a probing pocket depth (PPD) reduction is 
normally taken as an indicator of treatment success and means good control over the inflammatory process (2). To improve the results of the classic periodontal treatment, some alternative therapies have been suggested recently to decrease the number of bacteria and the expression of mediators of inflammation. Preliminary studies show promising results using probiotics for oral diseases such as caries and candidiasis. Probiotics are living microorganisms which, when administered in adequate amounts, confer a health benefit for the host (3). However, there is in vitro and animal evidence that probiotic preparations comprised of dead cells and their metabolites can also exert a biological response (4). Probiotics' exact mechanism of action in the oral cavity isn't fully understood: there may be a direct interaction with the dental plaque, disrupting the biofilm owing to their antimicrobial products and competitive adhesion, and an indirect action as well, modulating the host's immune response.

The aim of this study was to review the adjuvant effects of different probiotic strains together with root scaling on the clinical outcomes of chronic periodontitis (CP) patients.

\section{Material and Methods}

- Study design

This was a systematic review carried out using the PRISMA Statement as a reporting guide (5).

- Eligibility criteria

Only randomised clinical trials in English were considered. Eligible trials had to compare combined manual therapy and probiotics, or manual therapy and placebo. A reduction in probing pocket depth (PPD) was the main outcome measure. Secondary outcome measures were: bleeding on probing (BOP), plaque index (PI), and bacteria counting. Non-randomised clinical trials, studies conducted in animals and those including patients with a healthy periodontium or experimental gingivitis were excluded.

- Search strategy and study selection

We conducted an electronic search in Medline (via PUBMED) with controlled vocabulary (MeSH) using the following keywords: "Probiotics" and "Periodontal Disease", with no date restrictions. Last search was conducted in December of 2017. Relevant articles were selected and assessed, and cross-referencing from these sources was used to identify additional trials. The trials identified were screened by two independent reviewers to determine whether they met or not the inclusion criteria. Any disagreement was resolved after discussion.

- Data collection process

Studies that fulfilled the inclusion criteria were processed for quality assessment. Data were recorded according to the criteria outlined by the Cochrane Collaboration, as done by other authors (6).
- Data items

The following items were recorded: year of publication, study design and duration; size of sample and stage of the disease; test and control interventions, including probiotic strains and any pre-treatment, vehicle, dose, frequency and length of consumption. We recorded the following outcomes: reduction in probing pocket depth, reduction of sites with bleeding on probing, reduction of plaque index scores, changes in bacteria concentration at any site of the oral cavity.

- Risk of bias in individual studies

The risk of bias of the individual studies was assessed according to the Cochrane Handbook for Systematic Reviews of Interventions (6) (high, unclear or low) according to the assessment of the following items: generation of allocation sequences, allocation concealment, blinding of participants and personnel, blinding of outcome assessment, incomplete outcome data, presence of biases in outcome reporting and other sources of bias that could influence the study's validity. Studies were defined as low risk of bias if all criteria were met. When missing one of these criteria, the study was classified as moderate, and it resulted in a high potential risk when two or more were missing.

- Data analysis

Data extraction revealed considerable heterogeneity of the included studies so that a meta-analysis could not be carried out. Instead of that, data were pooled into tables and figures and a descriptive summary was generated to report on study characteristics, results and dissimilarities.

\section{Results}

- Study selection

From 74 identified studies, six papers fulfilled the eligibility criteria, and three more studies were included from references. The flowchart of the retrieved studies is presented in Fig. 1.

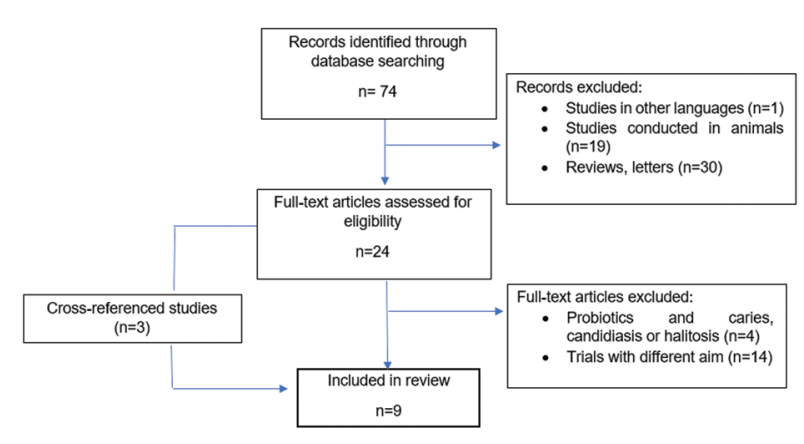

Fig. 1: Flowchart of the process of study selection. 
- Characteristics of studies included in the review

Nine randomised control trials published between 2013 and 2016 were included. (3,7-14) Eight trials (3,7-13) used a parallel-arm design, and one of the studies (14) used a split-mouth design. Considerable heterogeneity was observed in all trials with respect to evaluation period, age of participants and case definition (as some used Van der Welden's (15) definition whereas others used Armitage's (16)). The main characteristics of the studies are displayed in Table 1.

Table 1: Main characteristics of the included studies.

\begin{tabular}{|c|c|c|c|c|c|}
\hline Study & $\begin{array}{c}\text { Study design, } \\
\text { duration }\end{array}$ & $\begin{array}{c}\text { No. of } \\
\text { participants } \\
\text { baseline (end), } \\
\text { gender, age } \\
\text { (mean/range) }\end{array}$ & Case definition & $\begin{array}{l}\text { Probiotic (strain), } \\
\text { dose of each strain } \\
\text { per capsule }\end{array}$ & Intervention \\
\hline $\begin{array}{l}\text { Laleman et al. } \\
2015\end{array}$ & $\begin{array}{c}\text { RCT, parallel } \\
24 \text { weeks }\end{array}$ & $\begin{array}{c}48(48) \\
26 \overbrace{}^{\lambda} ; 22+ \\
46,5 / 37-58\end{array}$ & $\begin{array}{c}\text { Untreated moderate- } \\
\text { severe CP (Van der } \\
\text { Velden 2005) }\end{array}$ & $\begin{array}{l}\begin{array}{c}\text { Streptococcus oralis } \\
(\mathrm{KJ} 3)\end{array} \\
\text { S. uberis }(\mathrm{KJ} 2), S \\
\text { rattus }(\mathrm{JH} 145) \\
\geq 10^{8} \mathrm{CFU} / \mathrm{ml}\end{array}$ & $\begin{array}{l}\text { OHI + full-mouth one-stage } \\
\text { disinfection* } \\
1 \text { lozenge sucking } / 12 \mathrm{~h} / 3 \\
\text { months }\end{array}$ \\
\hline $\begin{array}{l}\text { Tekce et al. } \\
2015\end{array}$ & $\begin{array}{c}\text { RCT, parallel } \\
\text { 1 year }\end{array}$ & $\begin{array}{c}40(40) \\
18 \overbrace{}^{\lambda} ; 22+ \\
42,2 / 35-50\end{array}$ & $\begin{array}{l}\text { Horizontal bone loss } \\
\geq 2 \text { teeth with PD } \\
5-7 \mathrm{~mm} \text { in one ap- } \\
\text { proximal site } \\
\text { GI } \geq 2 \text { in each quad- } \\
\text { rant }\end{array}$ & $\begin{array}{c}\text { Lactobacillus reuteri } \\
1 \times 10^{8} \mathrm{CFU} / \mathrm{ml}\end{array}$ & $\begin{array}{c}\text { OHI + SRP (2 visits, 1-week } \\
\text { intervals) } \\
1 \text { lozenge sucking } / 12 \mathrm{~h} / 3 \\
\text { weeks }\end{array}$ \\
\hline $\begin{array}{l}\text { Teughels et } \\
\text { al. } 2013\end{array}$ & $\begin{array}{c}\text { RCT, parallel } \\
12 \text { weeks }\end{array}$ & $\begin{array}{c}30(30) \\
15 \overbrace{}^{\lambda} ; 15+ \\
46,17 / \geq 35\end{array}$ & $\begin{array}{l}\text { Untreated moderate- } \\
\text { severe CP (Van der } \\
\text { Velden 2005) }\end{array}$ & $\begin{array}{c}\text { L. reuteri } \\
\text { (DSM17938 and } \\
\text { ATCC PTA5289) } \\
1 \times 10^{8} \mathrm{CFU} / \mathrm{ml} \\
\end{array}$ & $\begin{array}{c}\text { OHI + full-mouth one-stage } \\
\text { disinfection* } \\
1 \text { lozenge sucking } / 12 \mathrm{~h} / 3 \\
\text { months }\end{array}$ \\
\hline $\begin{array}{c}\text { Penala et al. } \\
2015\end{array}$ & $\begin{array}{c}\text { RCT, parallel } \\
12 \text { weeks }\end{array}$ & $\begin{array}{c}32(29) \\
\text { No data } \\
36,25 / 25-59\end{array}$ & $\begin{array}{c}\geq 4 \text { teeth with PD } \\
\geq 5 \mathrm{~mm} \\
\text { CAL } \geq 4 \mathrm{~mm} \\
\text { Clinically perceptible } \\
\text { halitosis }\end{array}$ & $\begin{array}{l}\text { L. reuteri }+ \text { L. sali- } \\
\text { varius } \\
2 \times 10^{9} \mathrm{CFU} / \mathrm{ml}\end{array}$ & $\begin{array}{l}\mathrm{OHI}+\mathrm{SRP} \text { in two consecu- } \\
\text { tive days } \\
\text { Mouthwash } 1 / 10 \mathrm{ml} 1 \text { ' twice a } \\
\text { day for } 2 \text { weeks }\end{array}$ \\
\hline $\begin{array}{l}\text { Morales et al. } \\
2016\end{array}$ & $\begin{array}{c}\text { RCT, parallel } \\
1 \text { year }\end{array}$ & $\begin{array}{c}28(28) \\
14 \widehat{\delta} ; 14+ \\
49,8 / 35-68\end{array}$ & $\begin{array}{l}\geq 5 \text { teeth with PD } \\
\quad \geq 5 \mathrm{~mm} \\
\text { BOP } 20 \geq 3 \mathrm{~mm} \\
\text { Bone loss in RX }\end{array}$ & $\begin{array}{l}\text { L. rhamnosus SP1 } \\
2 \times 10^{7} \mathrm{CFU} / \mathrm{ml}\end{array}$ & $\begin{array}{l}\text { OHI + SRP in } 4-6 \text { visits at } \\
\text { one-week intervals } \\
\text { SPT every } 3 \text { months } \\
\text { Lozenge in } 150 \mathrm{ml} \text { of water } \\
\text { once a day for } 3 \text { months }\end{array}$ \\
\hline $\begin{array}{l}\text { Ince et al. } \\
2015\end{array}$ & $\begin{array}{c}\text { RCT, parallel } \\
1 \text { year }\end{array}$ & $\begin{array}{c}30(30) \\
17 \hat{\jmath} ; 13+ \\
41,6 / 30-50\end{array}$ & $\begin{array}{c}\text { Untreated CP (Armit- } \\
\text { age, 1999) }\end{array}$ & $\begin{array}{c}\text { L. reuteri } \\
\text { Not mentioned }\end{array}$ & $\begin{array}{c}\text { OHI + SRP in two sessions at } \\
\text { one-week intervals } \\
1 \text { lozenge sucking } / 12 \mathrm{~h} / 3 \\
\text { weeks }\end{array}$ \\
\hline $\begin{array}{l}\text { Vivekananda } \\
\text { et al. } 2010\end{array}$ & $\begin{array}{l}\text { RCT, split- } \\
\text { mouth } \\
42 \text { days }\end{array}$ & $\begin{array}{c}30(30) \\
19 \widehat{\jmath} ; 11 \text { + } \\
135-50\end{array}$ & $\begin{array}{c}\text { Gingivitis } \\
\text { PD 5-7mm } \\
\text { Bone loss clinically } \\
\text { and RX } \\
\end{array}$ & $\begin{array}{c}\text { L. reuteri } \\
\text { (DSM17938 and } \\
\text { ATCC PTA5289) } \\
1 \times 10^{8} \mathrm{CFU} / \mathrm{ml}\end{array}$ & $\begin{array}{c}\mathrm{OHI}+\mathrm{SRP} \text { in two quadrants } \\
\begin{array}{c}1 \text { lozenge sucking } / 12 \mathrm{~h} / 21 \\
\text { days from day } 21\end{array}\end{array}$ \\
\hline $\begin{array}{c}\text { Iwasaki et al. } \\
2016\end{array}$ & $\begin{array}{c}\text { RCT, parallel } \\
12 \text { weeks }\end{array}$ & $\begin{array}{c}39(36) \\
13 \overbrace{}^{\lambda} ; 23 q\end{array}$ & $\begin{array}{c}\text { Supportive periodon- } \\
\text { tal therapy } \\
\text { Initial PD } \geq 4 \mathrm{~mm} \\
\end{array}$ & $\begin{array}{l}\text { L. plantarum } \mathrm{HK} \\
\text { L-137 } \\
\text { Not mentioned } \\
\end{array}$ & $\begin{array}{c}\text { OHI + SPT (once a month) } \\
1 \text { capsule/day }(20 \% \text { probiotic, } \\
80 \% \text { dextrin) } / 3 \text { months }\end{array}$ \\
\hline $\begin{array}{l}\text { Hallström et } \\
\text { al. } 2016\end{array}$ & $\begin{array}{l}\text { RCT, parallel } \\
26 \text { weeks }\end{array}$ & $\begin{array}{c}49(46) \\
18 \hat{\jmath} ; 31 \text { + } \\
58,5 / 24-85\end{array}$ & $\begin{array}{l}\geq 1 \text { implant } \\
\mathrm{PD} \geq 4 \mathrm{~mm} \\
\text { Blood or pus }\end{array}$ & $\begin{array}{c}\text { L. reuteri } \\
\text { (DSM17938 and } \\
\text { ATCC PTA5289) } \\
2 \times 10^{7}\end{array}$ & $\begin{array}{c}\text { OHI + manual debridement } \\
\text { Topical application with a } \\
\text { probe } \\
1 \text { lozenge } / 12 \mathrm{~h} / 3 \text { months }\end{array}$ \\
\hline
\end{tabular}

$\mathrm{RCT}=$ randomised controlled trial; $\mathrm{CP}=$ chronic periodontitis; $\mathrm{OHI}=$ oral hygiene instructions; $\mathrm{SRP}=\mathrm{scaling}$ and root planning. *According to Quirynen et al.'s procedure. 
Subject characteristics

Sample sizes ranged between 28 and 49 participants, with an overall baseline sample size of 326 participants. A sum of nine patients were lost to follow up, in three studies $(8,11,13)$. The gender distribution was mostly reported for the total sample, except in the study of Penala (8). Two studies $(12,13)$ allowed for current smokers, whereas two exclude patients with a history of smoking $(8,10)$, three exclude current smokers only $(3,7,9)$ and one doesn't mention this criterion (11). The effect of smoking status on the outcome parameters wasn't subanalysed. Good general health was an inclusion criterion for seven studies $(3,7-10,12,14)$. Hallström et al. (13) excluded patients with a history of Diabetes mellitus only, and Iwasaki et al. (11) doesn't mention anything about the baseline health status.

Case definition

Specific selected patients diagnosed with untreated chronic periodontitis were included in seven of the studies $(3,7-10,12,14)$. One of these studies (8) used the presence of clinically perceptible halitosis estimated on an organoleptic score as an additional inclusion criterion. One study (11) took patients undergoing a supportive periodontal therapy (SPT) with an initial PD of $\geq 4 \mathrm{~mm}$. Patients with periimplantitis in at least one implant (a $\mathrm{PD} \geq 4 \mathrm{~mm}$ and presence of pus or bleeding) were included in the study of Hallström et al. (13) As the definition of chronic periodontitis differs between all studies, it is shown in Table 1.

Probiotics and intervention procedures

The strains of probiotics used were: $L$. reuteri (7,9,10,13,14), L. reuteri plus, L. salivarius (8), Streptococcus oralis, $S$. uberis and S. ratus (3), L. rhamnosus (12) and L. plantarum (11). All patients were given oral hygiene instructions before treatment, continued by a scaling and root planning in two consecutive days $(3,7,8)$ according to Quirynen's procedure (17) two sessions at one-week intervals $(9,10)$ or four to six sessions at one-week intervals (12). Only one study (12) performed supportive periodontal therapy (SPT) afterwards, every three months during the evaluations. In one of the studies (11) all patients had undergone a periodontal treatment before the start of the trial and were under an SPT program every month. Probiotic administration was started at the onset of the initial therapy in four studies $(9-11,13)$, after the last session of scaling in four studies $(3,7,8,12)$ and 21 days after treatment in one study (14). The administration routes were as follows: taking capsules (11), tablet dissolution in mouth $(3,7,9,10,13,14)$, tablet dissolution in $150 \mathrm{ml}$ of water $(12)$, subgingival irrigation plus mouthwash (8) and topical application of ointment (13). Treatment duration ranged from 3 weeks to 3 months (Table 1).

Side effects \& industry funding

All studies evaluated the presence of side effects. No adverse events were reported during the follow-up period. Study funding and supporting grants were mentioned in eight studies, (3,7-10,12-14) and in one study (11) it was not mentioned, and they stated to prepare their own probiotic product.

- Risk of bias assessment of selected studies

The estimated potential risk of bias was considered to be "low" in 6 studies $(3,7,9-12)$, moderate in two $(8,13)$ and high in Vivekananda's (14) study.

- Study outcomes

Pocket probing depth (PPD)

Overall mean PPD at the beginning and at different time points is displayed in Table 2 .

Table 2: Intergroup comparison of overall PPD $(\mathrm{mm})$ reported at different time points (mean $\pm \mathrm{SD}$ ).

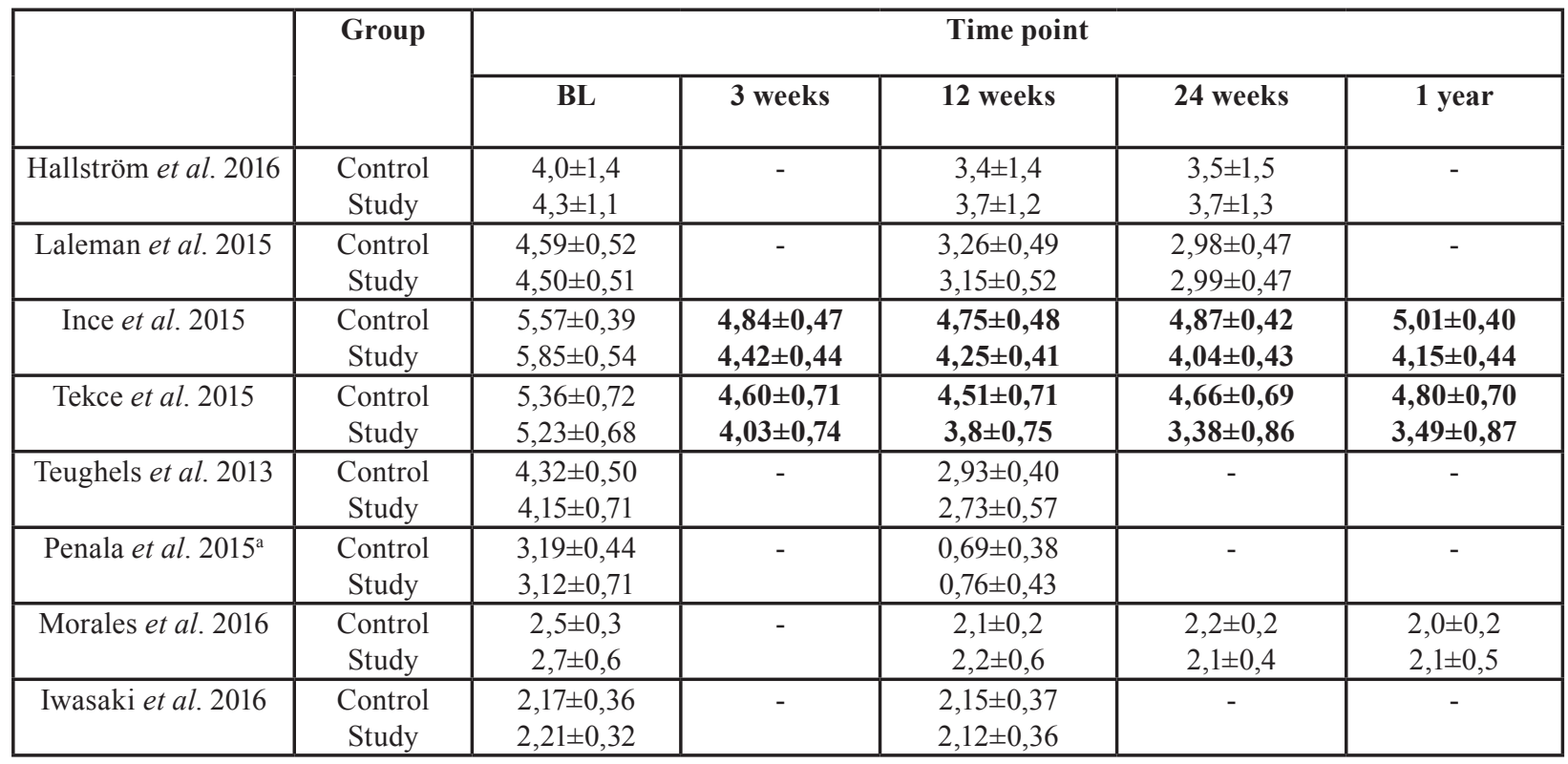

BL: baseline. Statistically significant results are shown in bold. aValues represent PPD reduction. 
Mean baseline PPD ranges between $2,17 \pm 0,36$ and $5,57 \pm 0,39 \mathrm{~mm}$ in the control group and $2,21 \pm 0,32$ and $5,85 \pm 0,54 \mathrm{~mm}$ for the study group. At 12 weeks, values range from $0,69 \pm 0,38$ to $4,75 \pm 0,48 \mathrm{~mm}$ and from $0,76 \pm 0,43$ to $4,25 \pm 0,41 \mathrm{~mm}$ for the control and study groups respectively. Statistically significant differences in favour of the study group were seen in two studies at all time points $(p<0,001)(9,10)$.

Four out of five studies that evaluated PPD reduction in moderate pockets $(4-6 \mathrm{~mm}$ ) found statistically significant differences between the control and study groups, with greater reductions for the study group. $(7-9,11)$ One study (3) found a greater reduction in the control group, which was not significant (Table 3).

Table 3: PPD reduction $(\mathrm{mm})$ in moderate pockets $(4-6 \mathrm{~mm})$ for each group at the end of the study.

\begin{tabular}{|c|c|c|c|}
\hline Study & $\begin{array}{c}\text { SRP }+ \\
\text { placebo }\end{array}$ & $\begin{array}{c}\text { SRP + } \\
\text { probiotics }\end{array}$ & $\boldsymbol{p}$ \\
\hline $\begin{array}{c}\text { Iwasaki } \text { et } \\
\text { al. } 2016^{\text {a }}\end{array}$ & 0,13 & 0,36 & $P<0,05$ \\
\hline $\begin{array}{c}\text { Penala } \text { et } \\
\text { al. } 2015^{\text {a }}\end{array}$ & $1,36 \pm 0,65$ & $1,89 \pm 0,25$ & $P=0,016$ \\
\hline $\begin{array}{c}\text { Tekce } \text { et al. } \\
2015^{\text {b }}\end{array}$ & $0,49 \pm 0,22$ & $0,87 \pm 0,30$ & $P=0,049$ \\
\hline $\begin{array}{c}\text { Teughels } \text { et } \\
\text { al. } 2013^{\text {a }}\end{array}$ & $1,84 \pm 0,22$ & $1,72 \pm 0,17$ & $P=0,041$ \\
\hline $\begin{array}{c}\text { Laleman } \text { et } \\
\text { al. } 2015^{\text {a }}\end{array}$ & $1,82 \pm 0,42$ & $1,78 \pm 0,38$ & $\mathrm{~ns}$ \\
\hline
\end{tabular}

${ }^{a}$ Measurement at 3 months; ${ }^{\text {b }}$ Measurement at 12 months; ns $=$ nonsignificant

Bleeding on probing (BOP)

The reduction in $\%$ of sites with $\mathrm{BOP}$ ranges between $3,70-59,5 \%$ and $0,70-77,85 \%$ for the control and study groups respectively. For chronic periodontitis, there is greater reduction in \% of sites with $\mathrm{BOP}$ at all time points with the use of probiotics in five studies $(7,9,10,12,14)$. Despite this tendency, only three trials $(9,10,14)$ found statistically significant differences when compared to the control group ( $p<0,005$ (9), $p<0,05$ (10) and $p<0,001$ (14)) (Fig. 2). Better results with the use of probiotics have been reported as well when using the bleeding index of Saxton, with a mean reduction of 1,34 and $1,08(p<0,002)(8)$. Two studies reported a larger reduction in the control group which wasn't statistically significant: $3,7 \%$ vs $0,7 \%$ (11) and $48 \pm 19 \%$ vs $47 \pm 17 \%$ (3) in control and study groups respectively. For periimplant mucositis, BOP sites were reduced from 54 to $14 \%$ in the study group and from 58 to $17 \%$ of sites in the control group, which was a statistically significant reduction from baseline but not between groups.

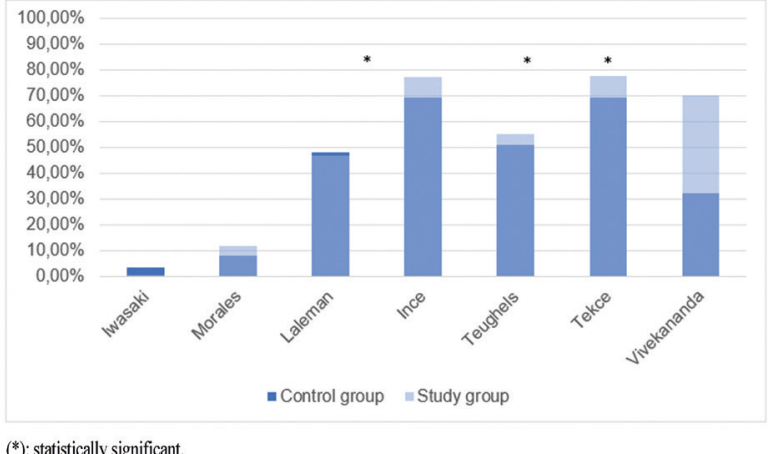

Fig. 2: Reduction in bleeding on probing ( $\%$ of sites) for chronic periodontitis.

Plaque index (PI)

Four trials $(3,7,12,13)$ used a dichotomous measurement for supragingival plaque accumulation and reported $\%$ of positive sites to plaque presence. Five trials $(8-11,14)$ report the mean of Löe and Silness' index (18). Larger reductions in plaque index are seen for study group in seven studies $(3,7-10,12,14)$ but three of them $(7,8,12)$ didn't find intergroup differences (Fig. 3).

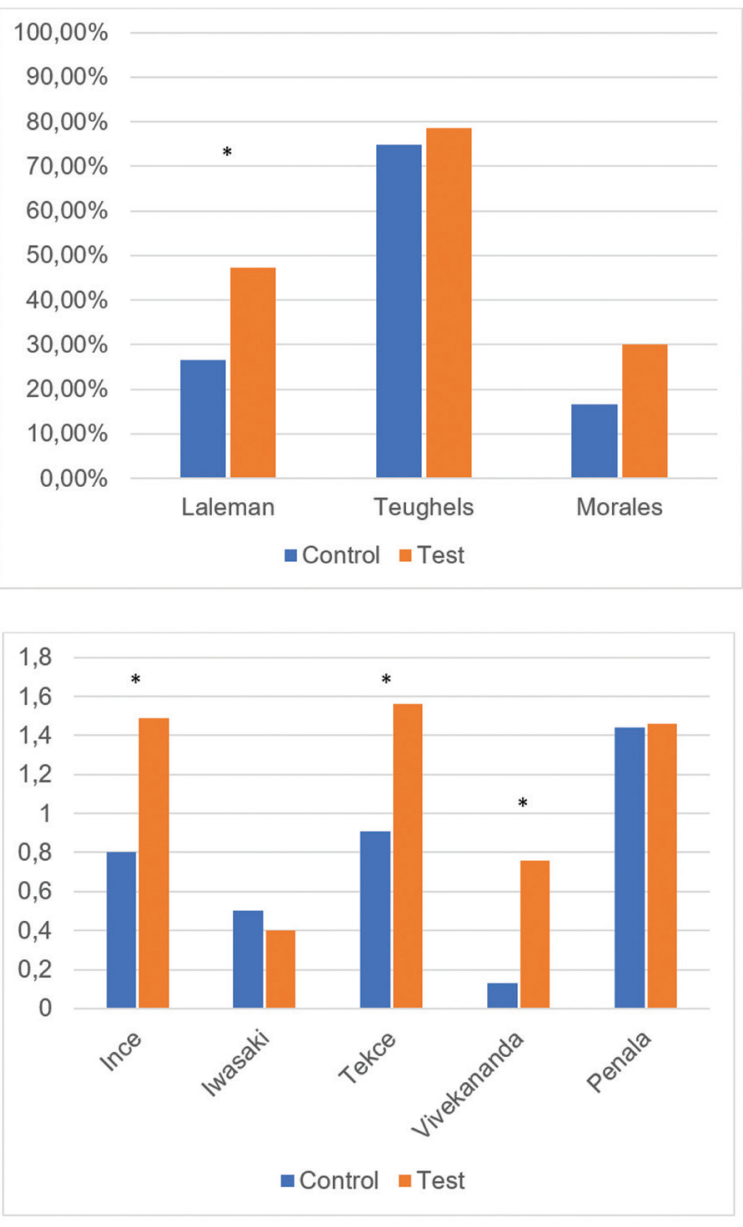

Fig. 3: Reduction of $\%$ of sites with plaque accumulation and reduction of mean plaque index (Löe and Silness plaque index). 
Biochemical and microbiological parameters

There is a significant reduction in red complex microorganisms at 1 month, which was higher for the study group, according to the BANA test (8). Between-group comparisons show a higher reduction of Aggregatibacter actinomycetencomitans, Porphyromonas gingivalis and Prevotella intermedia in subgingival plaque at 6-week evaluation for the study group $(p<0,005$, $p<0,005$ and $p<0,05$ respectively) (14), less concentration of Prevotella intermedia in saliva samples $(p<0,02)$ (3) and of Porphyromonas gingivalis in saliva, supragingival and subgingival plaque (7). Halitosis score, assessed subjectively on a scale of 0 to 5 , showed better results with the adjunctive use of probiotics (from $4 \pm 0,93$ to $0,4 \pm 0,51$ in the test group and from $4,43 \pm 0,51$ to $1,21 \pm 0,89$ in the control group) (8). One study (10) reported a significant decrease in MMP-8 and significant increase in TIMP-1 concentrations that was superior for all time intervals in the study group except day 360 .

\section{Discussion}

Chronic periodontitis is a multifactorial disease that arises from the interaction between three key factors: bacteria, the host's immune response and the environment. Initial therapy consists of a manual debridement of the periodontal pocket and oral hygiene instructions, in order to decrease the number of pathogenic bacteria. However, this shift to a less pathogenic microbiota is only temporary, even when combined with antiseptics or antibiotics (7). Probiotics seem to confer a beneficial effect to many infectious diseases, including those of the oral cavity. A direct interaction with pathogenic flora, a modulation of the immune response and the synthesis of antimicrobial products seem to be some of their mechanisms. Most studies conducted in humans use Lactobacillus and Bifidobacterium spp, even though other species such as Bacillus spp have shown promising results in experimental periodontitis in animals through the production of spores (19). Lactobacillus reuteri forms reuterin (3-hydroxipropionaldehyd), which induces oxidative stress in cells (9). Other suggested effects are: ability to compete with pathogens for epithelial cell adhesion (10), a reduction in the production of proinflammatory cytokines (TNF- $\alpha$, IL-1 $\beta$, IL-17), (20) a reduction in MMP-8 expression, which is the main collagenase involved in chronic periodontitis, and an increase of TIMP-1, which is a modulating factor of MMP activity. (10) On the other hand, Streptococcus sanguinis and Streptococcus uberis form hydrogen peroxide, a product that inhibits the growth of Aggregatibacter actinomycetencomitans (3). Such biological interactions could have a beneficial impact in clinical parameters of patients with chronic periodontitis.

No additional benefit is seen in terms of mean PPD except for the studies of Tekce et al. (9) and Ince et al. (10).
These studies have deeper baseline PPD and this could have influenced the greater differences between groups. Nevertheless, subanalyses show that different strains of Lactobacillus seem to decrease PPD in moderate periodontal pockets $(4-6 \mathrm{~mm})$ when compared to the use of placebo + SRP (7-9,11). This effect is not seen in the study of Laleman et al. (3) with the use of Streptococcus spp even though the inclusion criteria and intervention were identical to Teughels et al.'s (7) who used of $L$. reuteri. This could mean data obtained in vitro and in animal studies doesn't necessarily need to show beneficial results in humans, and not all strains of probiotics might be effective. Interestingly, two trials $(9,11)$ have less significant reductions than other authors. In the study of Tekce et al. (9), measurements took place at 360 days and without any periodontal support therapy. It could be possible that the beneficial effects of probiotics on moderate pockets were temporary and did not last for more than 3 months. In the study of Iwasaki et al. (11) mean values reported were not for mean PPD of pockets with 4-6mm but for PPD of teeth with pockets with $4-6 \mathrm{~mm}$ and that is why the baseline mean wasn't over 3,08 $\pm 0,34 \mathrm{~mm}$ for any group, compared with the other studies. Also, their patients were under a supportive periodontal therapy, meaning baseline periodontal pockets were not deep and probiotics might not be beneficial in such cases.

Statistically significant differences are seen in intergroup comparisons for BOP in favour of the use of Lactobacillus spp, but this was not seen after the use of Streptococcus spp (3). Iwasaki et al. (11) found no significant differences in this clinical parameter between the two groups $(3,70$ and $0,7 \%$ reduction for the control and study group respectively). Interestingly, their patients were under a SPT program, which includes a reinforcement of oral hygiene instructions, and this may have influenced such low bleeding throughout the study. Another study to perform SPT after the treatment was that carried out by Morales et al. (12). Similarly, the reduction in BOP was $8,30 \%$ for the control group and $11,70 \%$ for the study group. Tekce et al. (9) and Ince et al. (10) measure BOP at one year after 3-week consumption of $L$. reuteri lozenges with no additional TPS and obtain a reduction of $69,6 \%$ and $50,95 \%$ in the control group and $77,85 \%$ and $77,3 \%$ in the study group respectively. Teughels et al. (7) showed less BOP on the study group but didn't obtain statistically significant differences at 3-month evaluation despite using a similar methodology than the aforementioned studies. Also, administration routes other than lozenge dissolution have shown promising results according to Penala et al. (8) whose patients were told to mouthwash with a $L$. reuteri and $L$. salivarius product.

Microbiological and chemical effects are not reported in all trials. Vivekananda (14) was the first author to 
suggest $L$. reuteri's antimicrobial effect in short-term measurements in a split-mouth study, reporting that probiotic lozenges either alone or in combination with SRP decreased the counts of subgingival A. actinomycetencomitans, $P$. gingivalis and $P$. intermedia. Similar results for subgingival plaque were obtained by Tekce $e t$ al. (9) who reported larger reductions in obligate anaerobes at days 21, 90 and 180, but showed no difference between groups at day 360, suggesting the beneficial effects of probiotics are temporary. According to Teughels et al. (7), larger reductions in $P$. gingivalis were found in subgingival, supragingival and saliva samples over the 12-week period, as well as a reduction in $P$. intermedia in supragingival $(p=0,074)$ and saliva $(p<0,05)$ samples. On the other hand, Streptococcus spp. antimicrobial effect is not clear as Laleman et al. (3) found a significant intergroup difference only for $P$. intermedia in saliva at week $12(p=0,02)$ but did not find any difference for other anaerobe microorganisms, and no further investigation on the presence of the probiotic subgingivally was conducted. Little is known about the subgingival retention of the delivered probiotic as only the paper of Tekce et al. (9) considers this parameter. In his study, $L$. reuteri was detected in 6 and 11 patients the day 21 and 90 respectively, but the levels decreased by the end of the evaluation period. This indicates that probiotic colonization isn't immediate, is only temporary and isn't seen in all patients, what could explain differences in microbiological differences between studies.

When analysing the effect of probiotics in the management of periimplant mucositis, Hallström et al. (13) performed a manual debridement combined with professional topical application of a $L$. reuteri gel and prescription of $L$. reuteri lozenges twice a day for three months. They reported a general improvement in both the test and placebo groups, with a change in PPD at the implant's deepest site of 0,7-1,2 $\mathrm{mm}$ in both groups. Bleeding on probing was reduced in 40 and $41 \%$ in study and control groups respectively. They found a tendency to greater reduction in IL-1RA, IL-8, CCL5, TNF- $\alpha$ and GM-CSF in the crevicular fluid, but intergroup comparisons were not statistically significant for any parameter.

\section{Conclusions}

Probiotics may provide a safe additional benefit to manual debridement in clinical and biochemical parameters of chronic periodontitis. Nevertheless, more studies are required with larger cohorts on dose, route of administration and strains of probiotics used.

\section{References}

1. Sharma A, Raman A, Pradeep AR. Role of $1 \%$ alendronate gel as adjunct to mechanical therapy in the treatment of chronic periodontitis among smokers. Appl Oral Sci. 2017;25:243-9.

2. Donos N. The periodontal pocket. Periodontol 2000. 2018;76:7-15.
3. Laleman I, Yilmaz E, Ozcelik O, Haytac C, Pauwels M, Herrero ER, y cols. The effect of a Streptococci containing probiotic in periodontal therapy: a randomized controlled trial. J Clin Periodontol. 2015;42:1032-41.

4. Adams CA. The probiotic paradox: live and dead cells are biological response modifiers. Nutr Res Rev. 2010;23:37-46.

5. Liberati A, Altman DG, Tetzlaff J, Mulrow C, Gotzsche PC, Ioannidis JP et al. The PRISMA statement for reporting systematic reviews and meta-analyses of the studies that evaluate health care interventions: explanation and elaboration. J Clin Epidemiol. 2009;62:e1-34.

6. Bassir SH, Alhareky M, Wangsrimongkol B, Jia Y, Karimbux N. WSystematic review and meta-analysis of hard tissue outcomes of alveolar ridge preservation. Int J Oral Maxillofac Implants. 2018;33:979-94

7. Teughels W, Durukan A, Ozcelik O, Pauwels M, Quirynen M, Haytac MC. Clinical and microbiological effects of Lactobacillus reuteri probiotics in the treatment of chronic periodontitis: a randomized placebo-controlled study. J Clin Periodontol. 2013;40:1025-35.

8. Penala S, Kalakonda B, Pathakota KR, Jayakumar A, Koppolu P, Lakshmi BV, et al. Efficacy of local use of probiotics as an adjunct to scaling and root planing in chronic periodontitis and halitosis: a randomized controlled trial. J Res Pharm Pract. 2016;5:86-93.

9. Tekce M, Ince G, Gursoy H, Dirikan Ipci S, Cakar G, Kadir T, et al. Clinical and microbiological effects of probiotic lozenges in the treatment of chronic periodontitis: A 1-year follow-up study. J Clin Periodontol. 2015;42:363-72.

10. İnce G, Gürsoy H, İpçi ŞD, Cakar G, Emekli-Alturfan E, Yılmaz S. Clinical and biochemical evaluation of lozenges containing Lactobacillus reuteri as an adjunct to non-surgical periodontal therapy in chronic periodontitis. J Periodontol. 2015;86:746-54.

11. Iwasaki K, Maeda K, Hidaka K, Nemoto K, Hirose Y, Deguchi S. Daily intake of heat-killed Lactobacillus plantarum L-137 decreases the probing Depth in patients undergoing supportive periodontal therapy. Oral Health Prev Dent. 2016;14:207-14.

12. Morales A, Carvajal P, Silva N, Hernandez M, Godoy C, Rodriguez $\mathrm{G}$, et al. Clinical effects of Lactobacillus rhamnosus in nonsurgical treatment of chronic periodontitis: a randomized placebocontrolled trial with 1-year follow-up. J Periodontol. 2016;87:944-52. 13. Hallström H, Lindgren S, Widén C, Renvert S, Twetman S. Probiotic supplements and debridement of peri-implant mucositis: a randomized controlled trial. Acta Odontol Scand. 2016;74:60-6.

14. Vivekananda MR, Vandana KL, Bhat KG. Effect of the probiotic Lactobacilli reuteri (Prodentis) in the management of periodontal disease: a preliminary randomized clinical trial. J Oral Microbiol. $2010 ; 2$.

15. Van der Velden, U. Purpose and problems of periodontal disease classification. Periodontology 2000. 2005;39:13-21.

16. Armitage GC. Development of a classification system for periodontal diseases and conditions. Ann Periodontol. 1999;4:1-6.

17. Quirynen M, De Soete M, Boschmans G, Pauwels M, Coucke W, Teughels W, et al. Benefit of "one-stage full-mouth disinfection" is explained by disinfection and root planning within 24 hours: a randomized controlled trial. J Clin Periodontol. 2006;33:639-47.

18. Silness J, Löe H. Periodontal diseases in pregnancy (II) correlation between oral higiene and periodontal condition. Acta Odontol Scand. 1964;24:747-59.

19. Messora MR, Pereira LJ, Foureaux R, Oliveira LF, Sordi CG, Alves AJ, et al. Favourable effects of Bacillus subtilis and Bacillus licheniformis on experimental periodontitis in rats. Arch Oral Biol. 2016;66:108-19.

20. Szkaradkiewicz AK, Stopa J, Karpinski TM. Effect of oral administration involving a probiotic strain of Lactobacillus reuteri on proinflammatory cytokine response in patients with chronic periodontitis. Arch Immunol Ther Exp (Warsz). 2014;62:495-500.

\section{Funding}

No external funding was available for this study.

\section{Conflict of interest}

The authors declare that they have no conflicts of interest in relation to this study. 